\title{
HUBUNGAN KARAKTERISTIK PERAWAT TERHADAP TINGKAT \\ KEPATUHAN DALAM MELAKUKAN PENDOKUMENTASIAN \\ ASUHAN KEPERAWATAN
}

\section{SELLY FEBI MARGARETHA PANGGABEAN}

\author{
sellyfebi2601@gmail.com
}

\section{LATAR BELAKANG}

Dokumentasi dalam keperawatan memegang peranan penting terhadap segala macam tuntutan masyarakat yang semakin kritis dan mempengaruhi kesadaran masyarakat akan hakhaknya dari suatu unit kesehatan. Pendokumentasian merupakan suatu kegiatan pencatatan, pelaporan atau merekam suatu kejadian serta aktivitas yang dilakukan dalam bentuk pemberian pelayanan yang dianggap penting dan berharga (Dalami, 2011). Dokumentasi asuhan keperawatan menggunakan pendekatan proses keperawatan yang terdiri dari pengkajian, perumusan diagnosa, perencanaan, pelaksanaan, dan evaluasi sebagai metode ilmiah penyelesaian masalah keperawatan pada pasien untuk meningkatkan outcome pasien (Aziz, 2002). Ciri dokumentasi asuhan keperawatan yang baik adalah berdasarkan fakta (factual basis), akurat (accuracy), lengkap (completeness), ringkas (conciseness), terorganisir (organization), waktu yang tepat (time liness), dan bersifat mudah dibaca (legability) (Potter \& Perry; 2009). Prinsip-prinsip pendokumentasian direvisi menjadi tiga bentuk standar dokumentasi yaitu communication, accountability, dan safety (ANA, 2010). Dokumentasi asuhan keperawatan adalah suatu catatan yang memuat seluruh informasi yang dibutuhkan untuk menentukan diagnosis keperawatan, menyusun rencana keperawatan, melaksanakan dan mengevaluasi tindakan keperawatan, yang disusun secara sistematis, valid, dan dapat dipertanggung jawabkan secara moral dan hukum, disamping itu dokumentasi asuhan keperawatan juga merupakan bukti pencatatan dan pelaporan yang dimiliki perawat dalam melakukan asuhan keperawatan yang berguna untuk kepentingan pasien, perawat dan tim kesehatan dalam memberikan pelayanan dengan dasar komunikasi yang akurat dan lengkap secara tertulis dengan tanggung jawab 
perawat. Dokumentasi asuhan keperawatan juga mempunyai makna yang penting dalam keperawatan di rumah sakit, kurangnya kepatuhan perawat profesional mendokumentasikan asuhan keperawatan dengan benar dan jelas sesuai standar dapat berdampak pada pertanggungjawaban dalam aspek hukum, kualitas pelayanan, komunikasi antar tenaga kesehatan, referensi pendidikan, dan berkas/bahan dalam proses akreditasi.

Ketidakpatuhan perawat merupakan kunci kegagalan dalam pendokumentasian asuhan keperawatan. Ketidakpatuhan merupakan suatu kejahatan entitas, baik sengaja maupun tidaknya seseorang terhadap suatu rencana atau aturan (Utami, 2017; Meivinia, 2017). Ketidakpatuhan perawat dalam mendokumentasian asuhan keperawatan bisa mengakibatkan malpraktek dan duplikasi tindakan keperawatan yang dilakukan. Semakin banyak perawat yang tidak patuh mendokumentasikan asuhan keperawatan, maka akan semakin tinggi resiko terjadinya kesalahan dalam pemberian asuhan keperawatan, semakin kurang bukti pertanggung jawaban dan tanggung gugat perawat. Ada faktor - faktor yang mempengaruhi kepatuhan perawat dalam mendokumentasikan asuhan keperawatan, yaitu : faktor internal meliputi; pengetahuan, sikap, kemampuan, motivasi dan faktor eksternal meliputi; karakteristik kelompok kerja, karakteristik pekerjaan, dan karakteristik lingkungan. Karakteristik pekerjaan adalah identifikasi beragam dimensi pekerjaan yang secara simultan memperbaiki efesiensi organisasi dan kepuasan kerja. Ada pengaruh yang bermakna antara karakteristik pekerjaan terhadap prestasi kerja perawat. Adapun kajian ini bertujuan untuk menyimpulkan atau menganalisis hubungan perawat tentang karakteristik tingkat kepatuhan dalam melakukan pendokumentasian asuhan keperawatan.

\section{METODE}

Dalam kajian ini, metode yang digunakan adalah metode kualitatif, maksudnya ialah dengan cara mengumpulkan sebanyak - banyaknya data untuk dibaca, dianalisis, dan disimpulkan. Yaitu dengan literature review ini dengan menganalisis yang berfokus tentang hubungan perawat tentang karakteristik tingkat kepatuhan dalam melakukan pendokumentasian asuhan keperawatan. Adapun tinjauan literature review yang digunakan yaitu kajian jurnal online, textbook, e- book, dan sumber literature review lainnya yang berkaitan dengan judul kajian tersebut. Selanjutnya data yang telah dibaca, kemudian dianalisis dan disimpulkan dapat 
digunakan sebagai bahan pengambilan keputusan dalam menanggulangi permasalahan. Dengan menggunakan jurnal dan referensi yang digunakan pada literature review ini dengan tahun terbit paling lama tahun 2012, dengan jumlah minimal 10 referensi literature.

\section{HASIL}

Berdasarkan hasil yang dapat dianalisis dari berbagai sumber (literature review) bahwa ada beberapa faktor yang berkaitan dengan hubungan perawat tentang karakteristik tingkat kepatuhan dalam melakukan pendokumentasian asuhan keperawatan. Adapun hasil dari beberapa jurnal yang telah dibaca dan dianalisis terkait judul kajian diatas yaitu:

Dalam Jurnal Pertama yaitu, Hubungan Persepsi Perawat Tentang Karakteristik Pekerjaan Dengan Kepatuhan Dalam Pendokumentasian Asuhan Keperawatan. Jurnal Keperawatan Notokusumo Vol. IV, No. 1, Agustus 2016. Menurut hasil penelitian dari jurnal tersebut, dapat disimpulkan bahwa pada tabel ke 2 tentang (Persepsi perawat tentang karateristik pekerjaannya dan kepatuhan dalam pendokumentasian asuhan keperawatan) didapati bahwa sebagian besar perawat pelaksana memiliki persepsi dalam kategori baik terhadap karateristik pekerjaannya yakni 45 orang (72,6\%), sedangkan kriteria dalam kategori cukup 17 orang (27, 4\%). Begitu pula dengan kepatuhan dalam pendokumentasian asuhan keperawatan perawat pelaksana di Instalasi Rawat Inap RSUD Kota Mataram sebagian besar memiliki kepatuhan yang dalam kategori baik yakni 56 orang (90,3\%) sedangkan kriteria dalam kategori cukup 6 orang $(9,7 \%)$. Kemudian pada tabel ke 4 tentang (Kepatuhan dalam pendokumentasian asuhan keperawatan) didapati hasil observasi kepatuhan dalam pendokumentasian asuhan keperawatan perawat pelaksana di Instalasi Rawat Inap RSUD Kota Mataram sebagian besar memiliki pilihan dengan melakukan sesuai standar prosedur aspek yang dinilai dari pendokumentasian dengan rata - rata (79\%). Meskipun demikian, bila ditinjau secara detail maka masih ditemukan beberapa hal yang menyangkut ketidakpatuhan, didapati hasil pada aspek pengkajian yaitu: masih ada data yang dikaji tidak sesuai dengan pedoman; data tidak dikelompokkan berdasarkan bio-psiko-sosial- spiritual; masih ada perawat tidak melakukan pengkajian sampai pasien pulang, atau cenderung pengkajian hanya dilakukan saat pasien masuk rumah sakit; dan masalah kadang 
tidak dirumuskan berdasarkan kesenjangan antara status kesehatan dengan norma dan pola fungsi kehidupan.

Dalam Jurnal Kedua yaitu, Deskripsi Tingkat Kepatuhan Perawat Pelaksana Melakukan Dokumentasi Asuhan Keperawatan Di Ruang Rawat “ $K$ ” RS PGI Cikini Tahun 2015. Jurnal Akademi Keperawatan Husada Karya Jaya, Volume 1, Nomor 2. Menurut hasil dari penelitian jurnal tersebut, didapati hasil bahwa kepatuhan perawat melaksanakan pendokumentasian pengkajian menurut masa kerja 0-5 tahun patuh 100\% dan responden dengan masa kerja $>5-10$ tahun patuh 95,56\%, artinya responden dengan masa kerja 0-5 tahun lebih patuh dibanding dengan masa kerja >5-10 tahun. Maka rata - rata kepatuhan perawat yang melakukan pendokumentasian pengkajian dalam kategori tinggi yaitu 97,78 \%. Kemudian hasil dari kepatuhan perawat melaksanakan pendokumentasian diagnosa keperawatan dengan masa kerja 0-5 tahun patuh 76\% dan responden dengan masa kerja $>5-10$ tahun patuh $80 \%$, artinya responden dengan masa kerja >5-10 tahun lebih patuh melakukan pendokumentasian diagnosa asuhan keperawatan dibandingkan dengan responden dengan masa kerja 0-5 tahun. Maka rata rata kepatuhan perawat yang melakukan pendokumentasian diagnosa keperawatan didapati hasil dalam kategori tinggi yaitu $78 \%$.

Selanjutnya pada hasil kepatuhan perawat melaksanakan pendokumentasian intervensi dengan masa kerja 0-5 tahun patuh 97,5\% dan responden dengan masa kerja $>5-10$ tahun patuh $83,33 \%$, artinya responden dengan masa kerja 0-5 tahun lebih patuh dibanding dengan masa kerja >5-10 tahun. Maka rata - rata yang didapati pada hasil kepatuhan perawat melaksanakan pendokumentasian intervensi dalam kategori tinggi yaitu 90,415\%. Kemudian hasil penelitian tentang kepatuhan perawat melaksanakan pendokumentasian implementasi dengan masa kerja 05 tahun patuh 97,78\% dan responden dengan masa kerja $>5-10$ tahun patuh 96,3\%, artinya responden dengan masa kerja 0-5 tahun lebih patuh dibanding dengan masa kerja >5-10 tahun. Maka rata - rata yang didapati dari hasil penelitian tentang kepatuhan perawat melaksanakan pendokumentasian implementasi dalam kategori tinggi yaitu 97,04\%. Dan yang terakhir didapati hasil penelitian tentang kepatuhan perawat melaksanakan pendokumentasian evaluasi dengan masa kerja 0- 5 tahun patuh sebanyak 100\% dan responden dengan masa kerja $>5-10$ tahun patuh $100 \%$, artinya responden dengan masa kerja 0-5 dan >5-10 tahun sama-sama patuh 100\% melaksanakan pendokumentasian evaluasi hasil tindakan keperawatan. Dan didapati hasil rata - 
rata kepatuhan perawat melaksanakan pendokumentasian evaluasi dalam kategori tinggi yaitu $100 \%$.

Maka hasil dari perbandingan kedua jurnal tersebut dapat disimpulkan bahwa persepsi perawat tentang karateristik pekerjaannya, kepatuhan pendokumentasian asuhan keperawatan dan (pengkajian, diagnosa, intervensi, implementasi, serta evaluasi menurut pada masa kerja) memiliki hubungan yang penting dalam melakukan pendokumentasian dalam asuhan keperawatan. Jika prosedur - prosedur diatas tidak dilaksanakan, maka terjadi dampak negatif bagi pasien maupun akreditas rumah sakit serta dapat menurunkan mutu pelayanan keperawatan karena tidak dapat mengidentifikasi sejauh mana tingkat keberhasilan asuhan keperawatan yang telah diberikan.

\section{PEMBAHASAN}

\section{- Dokumentasi \& Kepatuhan Perawat Dalam Pendokumentasian Asuhan}

\section{Keperawatan}

Pendokumentasian merupakan bukti legal pelaksanaan pelayanan di rumah sakit. Kualitas pelayanan disuatu rumah sakit salah satunya dapat dilihat dari pelaksanaan pendokumentasian asuhan keperawatan (Wang, Hailey, \& Yu, 2011). Pendokumentasian berguna bagi rumah sakit dalam meningkatkan standar akreditasi, sebagai alat komunikasi antar profesi, indikator pelayanan mutu, bukti tanggung jawab, dan tanggung gugat perawat, sumber data dan sebagai sarana penelitian (Teytelman, 2002; Jefferies, Johnson, Nicholls \& Lad, 2012). Pendokumentasian yang tidak dilakukan dengan lengkap dapat menurunkan mutu pelayanan keperawatan karena tidak dapat mengidentifikasi sejauh mana tingkat keberhasilan asuhan keperawatan yang telah diberikan, dalam aspek legal perawat tidak mempunyai bukti tertulis jika klien menuntut ketidakpuasan akan pelayanan keperawatan (Nursalam, 2008; Iyer, 2001). Pendokumentasian asuhan keperawatan merupakan bagian penting dalam pemberian pelayanan kesehatan di rumah sakit, dan setiap pelaksanaannya tidak jauh dari lima proses keperawatan yang meliputi pengkajian, diagnosa, intervensi, implementasi, dan evaluasi (Prabowo, 2017; Potter \& Perry, 2010). Penerapan kelima proses ini masih menjadi permasalahan di berbagai 
rumah sakit di Indonesia. Hasil penelitian beberapa tahun terakhir melaporkan masih banyak angka ketidakpatuhan perawat dalam mendokumentasikan asuhan keperawatan.

Ketidakpatuhan perawat merupakan kunci kegagalan dalam pendokumentasian asuhan keperawatan. Ketidakpatuhan merupakan suatu kejahatan entitas, baik sengaja maupun tidaknya seseorang terhadap suatu rencana atau aturan (Utami, 2017; Meivinia, 2017). Menurut konsep asuhan keperawatan salah satu tujuan pendokumentasian adalah sebagai alat komunikasi, mekanisme pertanggung gugatan dan sebagai audit pelayanan keperawatan (Hidayat, 2009; Purwanti, 2012; Nurman, 2013). Semakin banyak perawat yang tidak patuh mendokumentasikan asuhan keperawatan maka akan semakin tinggi resiko terjadinya kesalahan dalam pemberian asuhan keperawatan, semakin kurang bukti tanggung jawaban dan tanggung gugat perawat. Sebagai upaya untuk menghindari hal ini, maka peran seorang manajer atau pimpinan keperawatan dalam pengelolaan dokumentasi proses keperawatan sangat penting, terutama terkait dengan ketidakpatuhan perawat. Ada berbagai hasil penelitian tentang ketidakpatuhan perawat dalam mendokumentasikan asuhan keperawatan telah dilakukan. Dan hasil dari penelitian tersebut melaporkan terdapat empat faktor yang menghambat kepatuhan perawat dalam mendokumentasikan asuhan keperawatan yaitu :(1) tidak seimbangnya jumlah tenaga perawat dengan pekerjaan yang ada, (2) format terlalu panjang, (3) rendahnya motivasi perawat mendokumentasikan, dan (4) pengetahuan perawat yang kurang baik (Aswar, Hamsinah, \& Kadir, 2014; Nuryani \& Hariyati, 2014; Pribadi, 2009). Selain dari hasil penelitian, beberapa teori kinerja menjelaskan faktor-faktor yang mempengaruhi kinerja perawat, termasuk kinerja dalam mendokumentasikan asuhan keperawatan. Banyak teori kinerja yang digunakan dalam bidang keperawatan, salah satunya adalah teori kinerja yang dikemukakan Gibson tahun 1987. Menurut konsep kinerja Gibson ada tiga variabel utama yang mempengaruhi kinerja seseorang yaitu : (1) variabel individu, (2) variabel organisasi dan (3) variabel psikologis.

Variabel individu meliputi kemampuan, keterampilan, latar belakang pendidikan, dan pengalaman kerja perawat dalam mendokumentasikan asuhan keperawatan. Sedangkan variabel organisasi meliputi sumber daya yang mendukung pelaksanaan pendokumentasian, kepemimpinan kepala ruangan dalam mentoring pelaksanaan pendokumentasian asuhan keperawatan. Dan yang terakhir, variabel psikologis yang meliputi persepsi, sikap, kepribadian, 
belajar dan motivasi perawat dalam mendokumentasikan asuhan keperawatan (Gibson, Ivancevich, Donnelly, \& Konopaske, 2012).

\section{- Karakteristik Perawat}

Karakteristik perawat menurut Kane, Shamliyan, Mueller, Duval, dan Wilt (2007) adalah meliputi usia, pengalaman atau masa kerja dan pendidikan. Menurut Hurst (2005), beban kerja yang tinggi di ruang perawatan menyebabkan kurang maksimalnya pelaksanaan dokumentasi kegiatan perawat.

\section{Umur}

Menurut Erikson rentang umur 25-45 tahun merupakan tahap perkembangan generativitas vs stagnasi, dimana seseorang memperhatikan ide-ide, keinginan untuk berbagi pengetahuan, dan meningkatkan kreativitas (Sunaryo, 2004). Didapati hasil sebuah asumsi peneliti, usia perawat dewasa muda pada umumnya mereka kurang memiliki rasa tanggung jawab, kurang disiplin, sering berpindah-pindah pekerjaan, belum mampu menunjukkan kematangan jiwa, dan belum mampu berpikir rasional. Perawat usia muda masih memerlukan bimbingan dan arahan dalam bersikap disiplin serta ditanamkan rasa tanggung jawab sehingga pemanfaatan usia produktif bisa lebih maksimal (Wahyudi,dkk., 2010).

\section{Jenis Kelamin}

Didapati dari hasil sebuah penelitian, menunjukkan bahwa pekerjaan perawat masih banyak diminati oleh perempuan dibandingkan laki-laki karena keperawatan masih diidentikkan dengan pekerjaan yang cocok dan sesuai dengan sifat perempuan yang lebih sabar, lemah lembut, dan peduli (Ilyas, 2001).

\section{Tingkat Pendidikan}

Berdasarkan tingkat pendidikan perawat,masih perlu ditingkatkan karena mayoritas tenaga perawat masih banyak di tingkat pendidikan DIII Keperawatan. Fenomena

yang ada pengetahuan yang sama tidak berarti mendorong individu untuk berperilaku sama dalam melakukan pendokumentasian asuhan keperawatan.

\section{Masa Kerja}

Hasil dari analisis penelitian menunjukkan bahwa rata-rata masa kerja perawat masih belum lama akan menyebabkan tuntutan pemenuhan kebutuhan masih kurang. 
Kondisi ini menunjukkan bahwa perawat mempunyai harapan yang relatif sudah terpenuhi karena belum mempunyai tuntutan kebutuhan yang tinggi dibandingkan dengan masa kerja yang sudah lama (Rusmianingsih, 2012).

\section{Pelatihan}

Pelatihan merupakan suatu fungsi manajemen yang perlu dilaksanakan terus menerus dan ini sangat penting dalam peningkatan kualitas dokumentasi asuhan keperawatan. Tingginya persentase perawat yang tidak pernah mengikuti pelatihan pendokumentasian disebabkan karena manajemen rumah sakit sudah lama tidak menyelenggarakan pelatihan pendokumentasian asuhan keperawatan.

\section{Hubungan umur dengan kualitas dokumentasi proses asuhan keperawatan}

Menurut teori semakin umur bertambah maka disertai dengan peningkatan pengalaman dan keterampilan (Gibson, 2001). Menurut penelitian dari hasil uji statistik, tidak ada hubungan antara umur dengan kualitas dokumentasi proses asuhan keperawatan. Makin lanjut usia seorang makin kecil tingkat kemangkirannya dan menunjukkan kemantapan yang lebih tinggi dengan masuk kerja lebih teratur (Farida, 2011). Bila dilihat dari aspek kesehatan, semakin tua lebih lama waktu pemulihan cedera maka kemungkinan tingkat kemangkiran yang lebih tinggi dibandingkan karyawan muda. Pengembangan berupa pendidikan dan pelatihan secara berkesinambungan, memberikan peluang untuk mengikutsertakan perawat senior dalam berbagai aktivitas di rumah sakit (Isesreni, 2008)

\section{Hubungan jenis kelamin dengan kualitas dokumentasi proses asuhan keperawatan}

Menurut Ilyas (2001) jenis kelamin akan memberikan dorongan yang berbeda, jenis kelamin laki-laki memiliki dorongan lebih besar daripada wanita karena tanggung jawab laki-laki lebih besar. Menurut penelitian dari hasil uji statistik, tidak ada hubungan antara jenis kelamin dengan kualitas dokumentasi. Mayoritas perawat berjenis kelamin wanita maka terlihat bahwa tidak ada proporsi perawat pelaksana dalam pendokumentasian asuhan keperawatan yang baik dan kurang baik sehingga diharapkan teradapat variasi jenis kelamin laki-laki dan perempuan maka pendokumentasian keperawatan akan lebih baik. 


\section{Hubungan tingkat pendidikan dengan kualitas dokumentasi proses asuhan keperawatan}

Perawat dengan tingkat pendidikan yang berbeda mempunyai kualitas dokumentasi yang dikerjakan berbeda pula karena semakin tinggi tingkat pendidikannya maka kemampuan secara kognitif dan keterampilan akan meningkat (Notoadmojo, 2003). Menurut penelitian dari hasil uji statistik, tidak ada hubungan antara tingkat pendidikan dengan kualitas dokumentasi proses asuhan keperawatan. Pendidikan tetap menjadi indikator penting dalam upaya memperbaiki kinerja perawat kecenderungan untuk mempunyai kinerja lebih baik, kemampuan secara kognitif dan keterampilan juga semakin meningkat. Seorang perawat untuk melakukan analisa memerlukan kemampuan intelektual, interpersonal, dan teknikal yang memadai.

\section{Hubungan masa kerja dengan kualitas dokumentasi proses asuhan keperawatan} Menurut Robbin lama kerja turut menentukan kinerja seseorang dalam menjalankan tugas. Semakin lama seseorang bekerja semakin terampil dan semakin cepat dia menyelesaikan tugas tersebut (Farida, 2011). Menurut penelitian dari hasil uji statistik, tidak ada hubungan antara masa kerja dengan kualitas dokumentasi proses asuhan keperawatan. Hal ini dapat diasumsikan bahwa semakin bertambah lama kerja ternyata tidak menunjukkan peningkatan kualitas dokumentasi proses asuhan keperawatan bahkan semakin terjadi penurunan. Faktor tidak adanya hubungan antara masa kerja bisa disebabkan karena terjadi kejenuhan terhadap rutinitas pekerjaan dan kebiasaan pendokumentasian, dan bertambahnya lama kerja seorang perawat sebaiknya disertai dengan kegiatan untuk meningkatkan keterampilan, pengetahuan, dan kemampuan setiap individu agar tidak terjadi kejenuhan terhadap rutinitas sehingga kualitas dokumentasi menjadi lebih baik.

\section{Hubungan pelatihan pendokumentasian dengan kualitas dokumentasi proses} asuhan keperawatan

Menurut penelitian dari hasil uji statistik, bahwa tidak ada hubungan antara pelatihan dengan kualitas dokumentasi proses asuhan keperawatan. Menurut Notoatmodjo (2010) bahwa untuk meningkatkan kemampuan seseorang perlu dilakukan pelatihan. Hal tersebut ditambahkan Triton (2005) bahwa untuk meningkatkan kemampuan dan 
ketrampilan diperlukan pelatihan. Kualitas pelatihan juga mempengaruhi perawat yang mengikuti pelatihan pendokumentasian.

Pelatihan asuhan keperawatan dipengaruhi oleh beberapa faktor (Soeprijadi, 2006):

a. Faktor pelatih, dengan menggunakan pelatih yang profesional

b. Faktor peserta, pelatihan yang mempunyai rasa kebersamaan tinggi dilihat dari dinamika kelompok yang sangat mendukung ke arah proses belajar mengajar

c. Faktor metode pelatihan, metode yang tepat akan menimbulkan kegairahan belajar para peserta.

d. Faktor materi pelatihan yang disusun dengan baik akan menimbulkan ketekunan dari peserta pelatihan.

\section{PENUTUP}

Pendokumentasian adalah suatu tindakan yang mencapai atau merekam peristiwa dan objek maupun aktivitas pemberian jasa (pelayanan) yang dianggap berharga dan penting (Tungpalan, 1983 dalam Buku Dokumentasi Keperawatan Dinarti dkk, 2009). Masalah yang sering muncul dan dihadapi di Indonesia dalam pelaksanaan asuhan keperawatan adalah banyak perawat yang belum melakukan pelayanan keperawatan sesuai standar asuhan keperawatan, salah satunya ialah melakukan kepatuhan didalam asuhan keperawatan. Kepatuhan adalah perilaku sesuai aturan dan disiplin (KBBI, 2007). Kepatuhan perawat yang kurang dalam melaksanakan pendokumentasian asuhan keperawatan masih menjadi fenomena diberbagai rumah sakit. Fenomena ini tentu memiliki dampak yang negatif baik bagi mutu pelayanan rumah sakit maupun bagi pasien.

Berdasarkan karateristik perawat, menunjukkan bahwa umur tidak ada hubungannya dengan kualitas dokumentasi asuhan keperawatan, berbeda halnya dengan masa kerja dan pelatihan menunjukkan bahwa ada hubungan yang bermakna dengan pendokumentasian asuhan keperawatan. Hasil temuan dari penelitian yang telah dibaca dan dianalisis tersebut, dapat dijadikan referensi untuk memecahkan masalah terkait pelaksanaan pendokumentasian asuhan keperawatan yang dikaitkan dengan karakteristik perawat terhadap tingkat kepatuhan dalam melakukan pendokumentasian asuhan keperawatan. 


\section{DAFTAR PUSTAKA}

Muryani., Pertiwiwati, E., \& Setiawan, H. (2019). Kualitas Pendokumentasian Asuhan Keperawatan Di Ruang Rawat Inap (Studi Di Rsud Kalimantan Tengah). Nerspedia, 2(1), 27-32.

Putra, A.A., Rejeki, S., \& Kristina, T.N. (2016). Hubungan Persepsi Perawat Tentang Karakteristik Pekerjaan Dengan Kepatuhan Dalam Pendokumentasian Asuhan Keperawatan. Jurnal Keperawatan Notokusumo, 4(1), 1-11.

Rapar, R. A., Kundre, R., \& Kallo, V. (2018). Hubungan Kepuasaan Kerja Perawat dengan Pelaksanaan Pendokumentasian Keperawatan di Rumah Sakit GMIM Pancaran Kasih Manado. E-Jurnal Keperawatan (e-Kp), 6(1).

Saputra, M.A.S., Arif, Y., \& Priscilla, V. (2019). Mentoring Kepala Ruangan Meningkatkan Kepatuhan Perawat Dalam Pendokumentasian Asuhan Keperawatan. Jurnal 'Aisyiyah Medika, Volume 3, Nomor 2.

Simamora, R. (2009). Dokumentasi Proses Keperawatan.

Simamora, R. H., Purba, J. M., Bukit, E. K., \& Nurbaiti, N. (2019). Penguatan Peran Perawat Dalam Pelaksanaan Asuhan Keperawatan Melalui Pelatihan Layanan Prima. JPPM (Jurnal Pengabdian Dan Pemberdayaan Masyarakat), 3(1), 25-31.

Siswanto, L.M.H., Hariyati, R.T.S., \& Sukihananto. (2013). Faktor-Faktor Yang Berhubungan Dengan Kelengkapan Pendokumentasian Asuhan Keperawatan. Jurnal Keperawatan Indonesia, 16(2), 77-84.

Sitinjak, L., Halawa, S.F.D., Nazara, D., \& dkk. (2015). Deskripsi Tingkat Kepatuhan Perawat Pelaksana Melakukan Dokumentasi Asuhan Keperawatan Di Ruang Rawat "K" RS PGI Cikini Tahun 2015. Jurnal Akademi Keperawatan Husada Karya Jaya, Volume 1, Nomor2.

Syahida, A., Rahayu, D., \& Dani, T.R. (2019). Faktor Yang Berhubungan dengan Kepatuhan Perawat dalam Pelaksanaan Dokumentasi Asuhan Keperawatan di Ruang Rawat Inap Mata Uroe BLUD RSUD Langsa. Jurnal Edukes, Vol. 2, No. 2 
Ulum, M. M., \& Wulandari, R. D. (2013). Faktor yang Mempengaruhi Kepatuhan Pendokumentasian Asuhan Keperawatan Berdasarkan Teori Kepatuhan Milgram. Jurnal Administrasi Kesehatan Indonesia, 1(3), 252-262

Wisuda, C.A., \& Putri, D.O. (2019). Kinerja Perawat Pelaksana Dalam Pendokumentasian Asuhan Keperawatan Di Instalasi Rawat Inap. Jurnal 'Aisyiyah Medika, 4(2), 230-238.

Yanti, R.I., \& Warsito, B.E. (2013). Hubungan Karakteristik Perawat, Motivasi, Dan Supervisi Dengan Kualitas Dokumentasi Proses Asuhan Keperawatan. Jurnal Managemen Keperawatan, 1(2), 107-114. 